Research Paper

\title{
Detection of enteric viruses in activated sludge by feasible concentration methods
}

\author{
Tatiana Prado ${ }^{1}$, Ana Maria Coimbra Gaspar ${ }^{2}$, Marize Pereira Miagostovich ${ }^{1}$ \\ ${ }^{1}$ Laboratório de Virologia Comparada e Ambiental, Instituto Oswaldo Cruz, Fundação Oswaldo Cruz, \\ Rio de Janeiro, RJ, Brazil. \\ ${ }^{2}$ Laboratório de Desenvolvimento Tecnológico em Virologia, Instituto Oswaldo Cruz, \\ Fundação Oswaldo Cruz, Rio de Janeiro, RJ, Brazil.
}

Submitted: August 5, 2012; Approved: September 9, 2013.

\begin{abstract}
Human enteric viruses are responsible to cause several diseases, including gastroenteritis and hepatitis, and can be present in high amounts in sewage sludge. This study compared virus recovery efficiency of two feasible concentration methods used for detecting human adenovirus (HAdV), rotavirus species A (RV-A), norovirus genogroup II (NoV GII) and hepatitis A virus (HAV) in sewage sludge from an activated sludge process. Twelve sewage sludge samples were collected bi-monthly from January to July, 2011. Ultracentrifugation was compared with a simplified protocol based on beef extract elution for recovering enteric viruses. Viruses were quantified by quantitative real-time PCR assays and virus recovery efficiency and limits of detection were determined. Methods showed mean recovery rates lower than $7.5 \%$, presenting critical limits of detection (higher than $10^{2}$ $10^{3}$ genome copies - GC L ${ }^{-1}$ for all viruses analyzed). Nevertheless, HAdV were detected in $90 \%$ of the analyzed sewage sludge samples (range: $1.8 \times 10^{4}$ to $1.1 \times 10^{5} \mathrm{GC} \mathrm{L}^{-1}$ ), followed by RV-A and NoV (both in 50\%) and HAV (8\%). Results suggesting that activated sludge is contaminated with high viral loads and HAdV are widely disseminated in these samples. The low virus recovery rates achieved, especially for HAV, indicate that other feasible concentration methods could be developed to improve virus recovery efficiency in these environmental matrices.
\end{abstract}

Key words: enteric viruses, sewage sludge, activated sludge process, virus concentration methods.

\section{Introduction}

Raw sewage sludge is an ideal system for assessing viral diversity. Recently, 234 known viruses were identified in these environmental matrices, including humans, plant, animals, algal viruses, as well as bacteriophages (Cantalupo et al., 2011).

Different species of pathogenic human enteric viruses may be present in raw sludge (Sano et al., 2003; Schlindwein et al., 2010; Cantalupo et al., 2011; Jebri et al., 2012), including members of the Picornaviridae family (hepatitis A virus - HAV), Caliciviridae (human noroviruses - NoV GI, GII and GIV) and Reoviridae (rotavirus species A - RV-A) (ICTV, 2011). HAV and NoV are the primary human viral pathogens of concern responsible to cause hepatitis and gastroenteritis in children and adults worldwide, but RV-A seems to be widely disseminated in wastewaters in Brazil (Fumian et al., 2011; Prado et al., 2011 ) and are the main responsible to cause acute gastroenteritis in children lower than 5 years old in developing countries (Linhares et al., 2011).

Human adenoviruses (HAdV) species A-G (family: Adenoviridae, genus: Mastadenovirus) (ICTV, 2011) are too recognized as important pathogens related to several diseases, including gastroenteritis, respiratory diseases, conjunctivitis, among others (Okoh et al., 2010). These viruses are largely disseminated in several environmental matrices (Bofill-Mas et al., 2006; Barrella et al., 2009; Okoh et al., 2010; Schlindwein et al., 2010; Prado et al., 2011) and have been considered as suitable index to evaluate water microbiological contamination (Bofill-Mas et al., 2006; Okoh et al., 2010; Schlindwein et al., 2010). 
However, many issues remain to be elucidated, such as attachment properties of viruses onto sludge flocs and variable removal rates for different viruses in WWTPs (Silva et al., 2007; Wen et al., 2009; Okoh et al., 2010; Simmons and Xagoraraki, 2011; Jebri et al., 2012). Moreover, there is a scarcity of information about enteric virus detection in sewage sludge, mainly for some viral groups, including rotavirus (RV) and norovirus (NoV) (Sidhu and Toze, 2009). The knowledge about viral contamination levels in sewage sludge is important to evaluate virus attachment properties onto sludge flocs and the capacity of the subsequent stabilization or disinfection processes in virus removal (Silva et al., 2007; Sidhu and Toze, 2009; Wen et al., 2009).

Molecular biology methods, notably PCR and their subsequently development by quantitative real-time PCR (qPCR) presents several advantages compared with other methods and can be incorporated into regular monitoring program to assess virus levels in wastewater effluents, mainly in developing countries (Girones et al., 2010; Okoh et al., 2010). However, natural inhibitors in environmental samples affect PCR performance and false negative results can be obtained, mainly for detecting enteric viruses in sewage sludge (Sano et al., 2003; Guzmán et al., 2007; Rock et al., 2010; Jebri et al., 2012).

Simplified concentration methods have been proposed for recovering viruses from sewage sludge (Sano et al., 2003; Guzmán et al., 2007), but detection sensitivity for different viral groups has not yet been established. Therefore, the aim of this study was to evaluate efficiency of two virus concentration methods used for detecting HAdV, RV-A, norovirus genogroup II (NoV GII) and HAV in sewage sludge from an urban wastewater treatment plant (WWTP) that uses activated sludge process, located in Rio de Janeiro city, Brazil.

For this purpose an ultracentrifugation method commonly used for concentrating viruses from wastewater samples (Heim et al., 2003; Bofill-Mas et al., 2006; Calgua et al., 2012; Jebri et al., 2012) was compared with a second virus concentration method based on beef extract elution (Guzmán et al., 2007), which is also recommended by a Resolution of the National Council of the Environment - CONAMA (Conama, 375/2006). This Resolution provides guidelines for monitoring enteric viruses in sewage sludge.

Quantitative PCR (qPCR) was used for viruses detection. The primers and probes used in TaqMan qPCR assays target more conservative regions of the virus genome and have been considered suitable for detecting enteric viruses in environmental and clinical samples (Heim et al., 2003; Villar et al., 2006; Fumian et al., 2010, 2011; Prado et al., 2011, 2012). Virus recovery rates and detection limits of the assays were also determined to avoid false negative results.

\section{Materials and Methods}

\section{Sampling collection at WWTP}

The urban WWTP analyzed in this study is located in the metropolitan area of Rio de Janeiro city, Brazil. The plant operates by a secondary treatment (conventional activated sludge process) with a mean inflow of $1600 \mathrm{~L} \mathrm{~s}^{-1}$. The treatment process begins with a preliminary treatment and primary sedimentation at a hydraulic retention time (HRT) of $2 \mathrm{~h}$. There are 4 aeration tanks placed in parallel that have the capacity to treat $625 \mathrm{~L} \mathrm{~s}^{-1}$ of effluent at an HRT of $4 \mathrm{~h}$. Secondary sedimentation is performed in secondary settling tanks at an HRT of $4 \mathrm{~h}$. The total HRT for the system is approximately of $12 \mathrm{~h}$. Twelve primary sewage sludge samples were collected bi-monthly ( 15 days intervals) from January to July, 2011. Sewage sludge samples (100 mL) were collected in sterile plastic bottles, kept on ice and transported to the laboratory for immediate analysis.

\section{Virus concentration methods}

Ultracentrifugation-based method initially described by Pina et al. (1998) for detecting enteric viruses from wastewaters was used for concentrate enteric viruses in sewage sludge. Minor modifications were performed. Briefly, $25 \mathrm{~mL}$ of sewage sludge was suspended in $10 \mathrm{~mL}$ of $25 \mathrm{mM}$ glycine buffer ( $\mathrm{pH} 9.5$ ). After incubation in ice for $30 \mathrm{~min}$, the solution was neutralized by the addition of $10 \mathrm{~mL}$ of $2 \mathrm{x}$ phosphate-buffered saline (PBS, $\mathrm{pH} 7.2$ ). The mixture was centrifuged $\left(12,000 \mathrm{~g}\right.$ for $15 \mathrm{~min}$ at $\left.4{ }^{\circ} \mathrm{C}\right)$ and the supernatant was submitted to an ultracentrifugation (Beckman ultracentrifuge) at $100,000 \mathrm{xg}$ for $1 \mathrm{~h}$ at $4{ }^{\circ} \mathrm{C}$. Pellet was resuspended in $1.0 \mathrm{~mL}$ of $1 \mathrm{x}$ PBS pH 7.2.

A second method based on elution with beef extract was performed as described by Guzmán et al. (2007). Briefly, a beef extract solution (10\%, pH 7.2, 10:1 (v/v) or (w/v) (LP029B, Oxoid Ltd. Basingstoke, Hants., England), was added in $25 \mathrm{~mL}$ of sewage sludge sample. The sample was stirred by magnetic stirring for $20 \mathrm{~min}$ at room temperature. After, the sample was centrifuged at 4,000 $g$ for 30 min at $4{ }^{\circ} \mathrm{C}$ (Thermo Scientific, Sorvall ST40 Centrifuge). The supernatant was recovered and filtered through a low protein binding $0.22 \mu \mathrm{m}$ pore size membrane filters (Millipore) for decontamination.

\section{Viruses and sludge spike experiments}

RVA G1P[8] (GenBank accession no. GU831596), NoV GII/4 strain (GenBank accession no. DQ997040) isolated from acute gastroenteritis outbreaks in Brazil were used in spiked experiments. HAdV serotype 5 propagated in cell culture (Hep-2) and HAV strain (HAF-203) in Rhesus kidney cell cultures (FRhK-4) were used to perform all experiments (Villar et al., 2006).

For spiked experiments, sludge samples were autoclaved at $121{ }^{\circ} \mathrm{C}$ for $30 \mathrm{~min}$ for decontamination. Viruses were spiked in $25 \mathrm{~mL}$ of the sludge sample and ad- 
sorbed onto sludge flocs by adjusting the $\mathrm{pH}$ to $3.5 \pm 0.1$ with $\mathrm{HCl}(1 \mathrm{M})$, as described by Sano et al. (2003) and stirring with a magnetic stirrer for $30 \mathrm{~min}$. The sludge samples were centrifuged $\left(10,000 \mathrm{~g}\right.$, for $15 \mathrm{~min}$ at $\left.4{ }^{\circ} \mathrm{C}\right)$ and pellet generated in each experiment were analyzed through concentration methods and Real-Time PCR assay for determining virus recovery yields. Procedures were performed in triplicate and repeated at different sampling dates. In all experiments, negative controls (decontaminated sewage sludge samples without viruses seeded) were also included.

Detection limits of methods were tested diluting initial spiked viral titers to the samples. Viral titers varying from $10^{4}$ to $10^{1}$ viral particles were inoculated in all experiments performed in triplicate.

\section{Viral genomic extraction and reverse transcription (RT) reaction}

Nucleic acids were extracted from $140 \mu \mathrm{L}$ of the eluate to obtain a final volume of $60 \mu \mathrm{L}$, using the QIAamp Viral RNA (Qiagen, Inc., Valencia, CA) according to the manufacturer's instructions.

cDNA synthesis was carried out by RT using a random primer $\left(\mathrm{PdN}_{6} ; 50 A_{260}\right.$ units; Amersham Biosciences, Chalfont St Giles, Buckinghamshire, UK) for RV, NoV, HAV $2 \mu \mathrm{L}$ of dimethyl sulfoxide (Sigma, St. Louis, MO) and $10 \mu \mathrm{L}$ of RNA were mixed briefly, heated at $97^{\circ} \mathrm{C}$ for 7 $\mathrm{min}$, and chilled in ice for $4 \mathrm{~min}$. The components of the mixture and their final concentrations for a $50-\mu \mathrm{L}$ RT reaction were carried out as follows: $2.5 \mathrm{mM}$ each deoxynucleoside triphosphate (GIBCO BRL, Life Technologies, Inc., Grand Island, NY), $1.5 \mathrm{mM} \mathrm{MgCl}_{2}, 200 \mathrm{U}$ of Superscript III reverse transcriptase (Invitrogen), and $1 \mu \mathrm{L}$ of $\mathrm{PdN}_{6}$. The RT reaction mixture was incubated in a thermal cycler (PTC-100 Programmable Thermal Controller; MJ
Research, Inc., Watertown, MA) at $25^{\circ} \mathrm{C}$ for $5 \mathrm{~min}, 50^{\circ} \mathrm{C}$ for $60 \mathrm{~min}$ and $70{ }^{\circ} \mathrm{C}$ for $20 \mathrm{~min}$.

\section{Virus quantification by Real-Time PCR}

Real-time PCR protocols including sequence of primers and probes, region of amplification of the genome and references can be found in Table 1. For all viruses, a standard curve (SC; $10^{8}$ to $10^{1}$ copies per reaction) was generated using a tenfold serial dilution of pCR2.1 vectors (Invitrogen, USA) containing the target region. The $\mathrm{qPCR}$ reaction was performed in the final volume of $25 \mu \mathrm{L}$ by using $12.5 \mu \mathrm{L}$ of the Universal PCR Master Mix (Applied Biosystems, CA, USA) and $5 \mu \mathrm{L}$ of the cDNA on the following incubation conditions: $50{ }^{\circ} \mathrm{C}$ for $2 \mathrm{~min}$ to activate $\mathrm{UNG}$, initial denaturation at $95^{\circ} \mathrm{C}$ for $10 \mathrm{~min}$, and then $40-45$ cycles of $95^{\circ} \mathrm{C}$ for $15 \mathrm{~s}$ and $50-60{ }^{\circ} \mathrm{C}$ for $1 \mathrm{~min}$. Amplification data were collected and analyzed using Applied Biosystems 7500 Software $^{\circledR}$ v2.0 (Applied Biosystems, Foster City, CA). All reactions were performed in duplicate. Positivity was considered when samples signals crossed the threshold line, presenting a characteristic sigmoid curve. The number of viral particles was determined by adjusting the values according to the volumes used for each step of the procedure (extraction, cDNA syntesis and qPCR reaction). The values (genome copies - GC) found in each methodology were reported in $\mathrm{ml}$ of concentrated samples.

\section{Results}

The results of virus recovery rates obtained by ultracentrifugation and beef extract methods used to concentrate sewage sludge samples are shown on Table 2. According to results it was possible to observe that both methods present virus recovery efficiency lower than $7.5 \%$. HAdV was better recovered by the two concentration methods and initial spiked viral titers of NoV and HAV were not detected

Table 1 - Viruses analyzed, PCRs assays, primers' sequences, genome region and references.

\begin{tabular}{|c|c|c|c|c|}
\hline $\begin{array}{l}\text { Viruses and } \\
\text { qPCR assay }\end{array}$ & Primers and probe & Sequences 5' to 3' & Genome region & References \\
\hline \multirow[t]{3}{*}{ RV-A RT-qPCR } & NSP3 F & ACCATCTWCACRTRACCCTCTATGAG ${ }^{\text {a }}$ & \multirow[t]{3}{*}{ NSP3 } & \multirow[t]{3}{*}{ Zeng et al., 2008} \\
\hline & NSP3 R & GGTCACATAACGCCCCTATAGC & & \\
\hline & NSP3 probe & VIC-AGTTAAAAGCTAACACTGTCAAA & & \\
\hline \multirow[t]{3}{*}{ HAdV qPCR } & AQ1 F & GCCACGGTGGGGTTTCTAAACTT & \multirow[t]{3}{*}{ Hexon } & \multirow[t]{3}{*}{ Heim et al., 2003} \\
\hline & AQ2 R & GCCCCAGTGGTCTTACATGCACATC & & \\
\hline & Probe & FAM-TGCACCAGACCCGGGCTCAGGTACTCCGA-TAMRA & & \\
\hline \multirow[t]{3}{*}{ NoV RT-qPCR } & $\mathrm{COG} 2 \mathrm{~F}$ & CARGARBCNATGTTYAGRTGGATGAG ${ }^{\mathrm{a}}$ & \multirow{3}{*}{$\begin{array}{l}\text { ORF1-ORF2 } \\
\text { junction region }\end{array}$} & \multirow[t]{3}{*}{ Kageyama et al., 2003} \\
\hline & COG2R & TCGACGCCATCTTCATTCACA & & \\
\hline & RING2-probe & FAM-TGGGAGGGCGATCGCAATCT-TAMRA & & \\
\hline \multirow[t]{3}{*}{ HAV RT-qPCR } & Forward primer & CTGCAGGTTCAGGGTTCTTAAATC & \multirow{3}{*}{$\begin{array}{l}5 \text { ' non-coding } \\
\text { region (NC) }\end{array}$} & \multirow[t]{3}{*}{ Villar et al., 2006} \\
\hline & Reverse primer & GAGAGCCCTGGAAGAAAGAAGA & & \\
\hline & Probe & FAM-ACTCATTTTTCACGCTTTCTG & & \\
\hline
\end{tabular}

${ }^{\mathrm{a}} \mathrm{IUB}$ code: $\mathrm{W}=\mathrm{A} / \mathrm{T}, \mathrm{R}=\mathrm{A} / \mathrm{G}, \mathrm{B}=\mathrm{C} / \mathrm{G} / \mathrm{T}, \mathrm{Y}=\mathrm{C} / \mathrm{T}, \mathrm{N}=\mathrm{A} / \mathrm{C} / \mathrm{G} / \mathrm{T}$. 
Table 2 - Virus recovery efficiency (\%) obtained by two concentration methods and qPCR results $\left(\mathrm{GC} \mathrm{mL}^{-1}\right)$ in primary sludge samples.

\begin{tabular}{|c|c|c|c|c|}
\hline Concentration method* & HAdV & RV-A & $\mathrm{NoV}$ & HAV \\
\hline \multicolumn{5}{|l|}{ Method 1} \\
\hline Virus titers spiked & $4.2 \times 10^{6}$ & $7.9 \times 10^{6}$ & $1.0 \times 10^{5}$ & $6.6 \times 10^{5}$ \\
\hline Recovery & $3.1 \times 10^{5}\left( \pm \mathrm{SD} 3.0 \times 10^{5}\right)$ & $1.0 \times 10^{4}\left( \pm \operatorname{SD} 8.6 \times 10^{3}\right)$ & $8.3 \times 10^{2}\left( \pm \mathrm{SD} 1.4 \times 10^{2}\right)$ & $4.3 \times 10^{4}\left( \pm \operatorname{SD} 3.2 \times 10^{4}\right)$ \\
\hline Recovery efficiency (\%) & 7.3 & 0.1 & 0.8 & 6.5 \\
\hline \multicolumn{5}{|l|}{ Method 2} \\
\hline Virus titers spiked & $4.2 \times 10^{6}$ & $7.0 \times 10^{6}$ & $1.5 \times 10^{4}$ & $6.0 \times 10^{5}$ \\
\hline Recovery & $1.8 \times 10^{5}\left( \pm \operatorname{SD} 1.4 \times 10^{5}\right)$ & $3.0 \times 10^{1}\left( \pm \operatorname{SD} 5.2 \times 10^{1}\right)$ & 0 & 0 \\
\hline Recovery efficiency (\%) & 4.2 & 0.0004 & 0 & 0 \\
\hline
\end{tabular}

*Methods were run in triplicate, $\mathrm{SD}=$ standard deviation. Method $1=$ ultracentrifugation, Method $2=$ beef extract.

by method 2 . RV-A was also very poorly recovered by this method.

Detection limits of the assays were tested diluting initial viral titers spiked into sludge samples. RV-A, NoV and HAV were not detected by method 2 when viral concentrations of $10^{3} \mathrm{GC} \mathrm{mL}^{-1}$ were seeded in sludge samples, but HAdV were detected (mean genome load recovery: $1.3 \mathrm{x}$ $\left.10^{2} \pm \mathrm{SD} 2.1 \times 10^{2} \mathrm{GC} \mathrm{mL}^{-1}\right)$. By using ultracentrifugation based-method, initial viral genome load of $\operatorname{HAdV}\left(4 \times 10^{3}\right.$ $\left.\mathrm{GC} \mathrm{mL}^{-1}\right)$, RV-A $\left(2.6 \times 10^{3} \mathrm{GC} \mathrm{mL}^{-1}\right)$ and $\mathrm{NoV}\left(4 \times 10^{3} \mathrm{GC}\right.$ $\mathrm{mL}^{-1}$ ) were detected at mean recovery rates as following: $1.2 \times 10^{3} \pm \mathrm{SD} 2 \times 10^{3} \mathrm{GC} \mathrm{mL}^{-1}$ for HAdV, $8 \times 10 \pm \mathrm{SD} 1.3 \times$ $10^{2} \mathrm{GC} \mathrm{mL}^{-1}$ for RV-A and $3.3 \times 10^{2} \pm \mathrm{SD} 5.7 \times 10^{2}$ for NoV, but HAV was negative when $10^{3} \mathrm{GC} \mathrm{mL}^{-1}$ was spiked. In concentrations of $10^{2}-10^{1} \mathrm{GC} \mathrm{mL}^{-1}$ all analysis showed negative results for viruses detection in both methods evaluated.
Table 3 shows the results for enteric viruses detected in naturally contaminated sewage sludge samples using two concentration methods. Method 2 (beef extract elution based method) was better for detecting HAdV, RV-A and NoV when compared with method 1 . HAV was only detected in one sample by the ultracentrifugation method (Table 3). The total frequency of detection, independently of used methods, demonstrated that HAdV was the most detected (91\%) (range: $1.8 \times 10^{4}$ to $1.1 \times 10^{5} \mathrm{GC} \mathrm{L}^{-1}$ ), followed by RV-A (range: $8 \times 10^{3}$ to $8 \times 10^{5} \mathrm{GC} \mathrm{L}^{-1}$ ), NoV (range: $1.6 \times 10^{4}$ to $4.9 \times 10^{5} \mathrm{GC} \mathrm{L}^{-1}$ ) (both $50 \%$ ) and $\mathrm{HAV}$ $(8 \%)\left(8.6 \times 10^{6} \mathrm{GC} \mathrm{L}^{-1}\right)$.

\section{Discussion}

Surveys on environmental virology need more focus on relevant issues addressed to ensure a reliable viral detec-

Table 3 - Viral genome loads $\left(\mathrm{GC} \mathrm{L}^{-1}\right)$ in sewage sludge obtained by concentration methods following detection using qPCR.

\begin{tabular}{|c|c|c|c|c|c|c|c|c|}
\hline \multirow{3}{*}{$\begin{array}{l}\text { Sampling date* } \\
\text { Methods }\end{array}$} & \multicolumn{8}{|c|}{ Viral groups } \\
\hline & \multicolumn{2}{|c|}{ HAdV } & \multicolumn{2}{|c|}{ RV-A } & \multicolumn{2}{|c|}{ NoV } & \multicolumn{2}{|c|}{ HAV } \\
\hline & 1 & 2 & 1 & 2 & 1 & 2 & 1 & 2 \\
\hline January & $2 \times 10^{4}$ & $7.4 \times 10^{4}$ & 0 & 0 & 0 & 0 & 0 & 0 \\
\hline \multirow[t]{2}{*}{ February } & 0 & $9.4 \times 10^{4}$ & 0 & 0 & 0 & 0 & $8.6 \times 10^{6}$ & 0 \\
\hline & 0 & $1.8 \times 10^{4}$ & 0 & 0 & 0 & 0 & 0 & 0 \\
\hline \multirow[t]{2}{*}{ March } & 0 & $1.1 \times 10^{5}$ & 0 & 0 & 0 & 0 & 0 & 0 \\
\hline & 0 & $4.9 \times 10^{4}$ & 0 & 0 & 0 & $2.4 \times 10^{5}$ & 0 & 0 \\
\hline \multirow[t]{2}{*}{ April } & $3.1 \times 10^{4}$ & $3.6 \times 10^{4}$ & 0 & 0 & 0 & 0 & 0 & 0 \\
\hline & 0 & $2.5 \times 10^{4}$ & 0 & $8 \times 10^{5}$ & 0 & $4.6 \times 10^{5}$ & 0 & 0 \\
\hline May & 0 & $1.1 \times 10^{5}$ & 0 & $8 \times 10^{3}$ & $2.4 \times 10^{4}$ & $4 \times 10^{5}$ & 0 & 0 \\
\hline \multirow[t]{2}{*}{ June } & 0 & 0 & $2 \times 10^{4}$ & 0 & 0 & 0 & 0 & 0 \\
\hline & 0 & $8.7 \times 10^{4}$ & 0 & $2.4 \times 10^{5}$ & $1.6 \times 10^{4}$ & $5.4 \times 10^{4}$ & 0 & 0 \\
\hline \multirow[t]{2}{*}{ July } & 0 & $5.3 \times 10^{4}$ & 0 & $4 \times 10^{5}$ & $4.9 \times 10^{5}$ & $1.2 \times 10^{5}$ & 0 & 0 \\
\hline & $2 \times 10^{4}$ & $7.4 \times 10^{4}$ & 0 & $1 \times 10^{5}$ & $5 \times 10^{4}$ & $2.4 \times 10^{4}$ & 0 & 0 \\
\hline Frequency of detection & $25 \%$ & $91 \%$ & $8 \%$ & $41 \%$ & $33 \%$ & $50 \%$ & $8 \%$ & 0 \\
\hline
\end{tabular}

Method $1=$ ultracentrifugation, Method $2=$ beef extract. * Samples were collected twice per month (except in Jan and May) with a 15 days intervals. 
tion, avoiding underestimation of the viruses presence in several environmental matrices. For this purpose, it is necessary the establishment of a suitable indicator to predict viral contamination levels in the environment. Second, virus recovery rates and limits of detection achieved by specific methods should be determined.

In this study, an ultracentrifugation based-method was used for recovering enteric viruses from sludge samples because it has been proven to present advantages over other concentration methods, with a mean recovery rate of $47 \%$ for RV-A in sewage (Fumian et al., 2010). However, very lower mean recovery rates were found for detecting enteric viruses in sewage sludge, demonstrating that these wastes contain higher inhibitor levels that can affect PCR performance.

Inhibitors are humic and fulvic acids, fats, proteins, organic and inorganic compounds, including polyphenols and heavy metals that form complexes with nucleic acids and inhibit amplification enzymes (Sano et al., 2003; Sidhu and Toze, 2009; Rock et al., 2010).

Simplified method based on beef extract elution that was previously tested for recovering coliphages from sewage sludge (Guzmán et al., 2007) was better for detecting HAdV, RV-A and NoV GII from naturally contaminated sewage sludge when compared with ultracentrifugation.

Rock et al. (2010) has reported that beef extract and glycine buffer can concentrate different inhibitor compounds responsible by causing different results when using qPCR assay. Nevertheless, it is difficult to determine which characteristic could affect qPCR efficiency, since ultracentrifugation was used in this study as a final strategy to concentrate viruses. Pellet generated can contain viruses and other substances, such as suspended solids of the final eluate, which could affect the procedure of nucleic acid extraction. Other studies have demonstrated that ultracentrifugation is not the better method used to recovering enteric viruses from water and wastewater samples (Albinana-Gimenez et al., 2009; Calgua et al., 2012). This method need acquisition of an ultracentrifuge and can be more expensive when compared with other methods (Calgua et al., 2012).

Limits of detection demonstrated that only relative high viral loads can be detected using elution with beef extract, but it seems to be applicable for sludge samples since these residues can contain high concentrations of pathogenic viruses, mainly HAdV.

HAdV have been proposed as a suitable index for the indication of viral contaminants of human origin since they were reported to occur worldwide throughout the year and are widely disseminated in several environments, being more resistant to sewage treatment processes, as suggested elsewhere (Bofill-Mas et al., 2006; Okoh et al., 2010; Schlindwein et al., 2010). In this study HAdV was the most detected virus in sewage sludge samples analyzed, similarly to another study reported in Brazil (Schilindwein et al., 2010) and seems that there isn't seasonal variation for their occurrence in environmental matrices, as verified previously (Barrella et al., 2009; Schilindwein et al., 2010).

Different seasonal patterns could be observed for other viruses. HAV was only detected in February, similarly to a recent study on HAV occurrence during the warmer and rainy seasons in wastewaters from Rio de Janeiro, Brazil (Prado et al., 2012).

NoV GII was predominantly detected in the colder months, suggesting a higher burden and circulation of these viruses during this period, which corroborates previous results about peaks of NoV occurrence in sewage samples in Brazil (Victoria et al., 2010). RV-A was also detected in the colder months, although seasonal variation has been not verified in wastewaters from Rio de Janeiro (Fumian et al., 2011).

RV-A was poorly detected in sewage sludge samples compared with AdV present in these samples, although recent studies have shown a large dissemination of RV-A ( $\geq 90 \%$ of detection) in wastewaters from Rio de Janeiro (Fumian et al., 2011; Prado et al., 2011). RV-A could be detected in higher frequencies in sewage sludge because are charged particles recognized to adsorb onto sludge flocs (Sidhu and Toze, 2009). Nevertheless, some authors have described that RV could poorly adsorb on solid fractions contained in sewage sludge (Arraj et al., 2005). Viral adsorption mechanisms in sewage sludge could vary according to distinct viruses types (Arraj et al., 2005; Silva et al., 2007) and these issues need further investigation.

The low frequency of RV-A found in these residues could also be related to limits of detection obtained by virus concentration methods and qPCR assays. Method based on beef extract elution seems to be not suitable for detecting RV in sewage sludge (Arraj et al., 2005).

The lower frequency of HAV detection in comparison with other enteric viruses in sewage sludge is in accordance with another study carried out in Brazil (Schilindwein et al., 2010). The real presence of HAV in these wastes could also be underestimated based on limits of detection of virus concentration methods, as recently reported (Jebri et al., 2012). Therefore, other virus concentration methods could be developed to improve virus recovery efficiency from sewage sludge.

Results also suggest that activated sludge samples are contaminated with higher viral genome loads than the observed. Based on data provided by previous studies in this WWTP (Fumian et al., 2011; Prado et al., 2012), sewage sludge samples can contain viral concentrations at least 1 to 2 log units more elevated than the raw sewage ones. Contamination levels of primary sewage sludge indicate that an adequate stabilization process should be employed to treat these wastes in activated sludge process.

It is also emphasized that the knowledge about viral contamination levels in sewage sludge and treated effluent of the current WWTPs could contribute to implement strat- 
egies or necessary alternatives to improve the performance of conventional sewage treatment processes and to ensure a better effluent and solid wastes quality in the near future.

\section{Acknowledgments}

The authors thank the staff of CEDAE (Water and Wastewater Sanitation Company - Rio de Janeiro - RJ) for kindly providing sewage sludge samples. This work was financially sponsored by the Conselho Nacional de Desenvolvimento Científico e Tecnológico (CNPq) / PAPES V, Brazil and by CGVAM/Ministry of Health, Brazil. This research work is within the scope of the activities of FIOCRUZ as a collaborating center of PAHO / WHO of Public and Environmental Health.

\section{References}

Albinana-Gimenez N, Clemente-Casares P, Calgua B, Huguet JM, Courtois S, Girones R (2009) Comparison of methods for concentrating human adenoviruses, polyomavirus JC and noroviruses in source waters and drinking water using quantitative PCR. J Virol Methods 158:104-109.

Arraj A, Bohatier J, Laveran H, Traore O (2005) Comparison of bacteriophage and enteric virus removal in pilot scale activated sludge plants. J Appl Microbiol 98:516-524.

Barrella KM, Garrafa P, Monezi TA, Hársi CM, Salvi C, Violante PABC, Mehnert UD (2009) Longitudinal study on occurrence of adenoviruses and hepatitis A virus in raw domestic sewage in the city of Limeira, São Paulo. Braz J Microbiol 40:102-107.

Bofill-Mas S, Albinana-Gimenez N, Clemente-Casares P, Hundesa A, Rodriguez-Manzano J, Allard A, Calvo M, Girones R (2006) Quantification and stability of human adenoviruses and polyomavirus JCPyV in wastewater matrices. Appl Environ Microbiol 72:7894-7896.

Calgua B, Rodriguez-Manzano J, Hundesa A, Suñen E, Calvo M, Bofill-Mas S, Girones R (2012) New methods for the concentration of viruses from urban sewage using quantitative PCR. J Virol Methods 187:215-221.

Cantalupo PG, Calgua B, Zhao G, Hundesa A, Wier AD, Katz JP, Grabe M, Hendrix RW, Girones R, Wang D, Pipas JM (2011) Raw sewage harbors diverse viral populations. mBIo. 2(5):e00180-11.

CONAMA - Conselho Nacional do Meio Ambiente (2006) Resolution 375 - Guidelines and procedures for use of sewage sludge in agriculture soil. Available at http://www.mma.gov.br/port/conama/res/res06/res37506.p df. Accessed 15 June 2012.

Fumian TM, Leite JPG, Castello AA, Gaggero A, Caillou MSL, Miagostovich MP (2010) Detection of rotavirus A in sewage samples using multiplex qPCR and an evaluation of the ultracentrifugation and adsorption-elution methods for virus concentration. J Virol Methods 170:42-46.

Fumian TM, Leite JPG, Rose TL, Prado T, Miagostovich MP (2011) One year environmental surveillance of rotavirus specie A (RVA) genotypes in circulation after the introduction of the Rotarix vaccine in Rio de Janeiro, Brazil. Water Res 45:5755-5763.
Girones R, Ferrús MA, Alonso JL, Rodriguez-Manzano J, Calgua B, Corrêa AB, Hundesa A, Carratala A, Bofill-Mas S (2010) Molecular detection of pathogens in water - The pros and cons of molecular techniques. Water Res 44:4325-4339.

Guzmán C, Jofre J, Blanch AR, Lucena F (2007) Development of a feasible method to extract somatic coliphages from sludge, soil, and treated biowaste. J Virol Methods 144:41-48.

Heim A, Ebnet C, Harste G, Pring-Akerblom P (2003) Rapid and quantitative detection of human adenovirus DNA by real-time PCR. J Med Virol 70:228-239.

ICTV - International Committee on Taxonomy of Viruses. (2011). Master Species List 2011 v2. Available at: http://talk.ictvonline.org/files/ictv_documents/m/msl/4090.aspx. Accessed 05 February 2013.

Jebri S, Jofre J, Barkallah I, Saidi M, Hmaied F (2012) Presence and fate of coliphages and enteric viruses in three wastewater treatment plants effluents and activated sludge from Tunisia. Environ Sci Pollut Res 19:2195-2201.

Kageyama T, Kojima S, Shinohara M, Uchida K, Fukushi F, Hoshino FB, Takeda N, Katayama K (2003) Broadly reactive and highly sensitive assay for Norwalk-like viruses based on real-time quantitative reverse transcription-PCR. J Clin Microbiol 41:1548-1557.

Linhares AC, Stupka JA, Ciapponi A, Bardach AE, Glujovsky D, Aruj PK, Mazzoni A, Rodríguez JAB, Rearte A, Lanzieri TM, Ortega-Barria E, Colindres R (2011) Burden and typing of rotavirus group A in Latin America and the Caribbean: systematic review and meta-analysis. Rev Med Virol 21:89-109.

Okoh AI, Sibanda T, Gusha SS (2010) Inadequately treated wastewater as a source of human enteric viruses in the environment. Int J Environ Res Public Health 7:2620-2637.

Pina S, Jofre J, Emerson SU, Purcell RH, Girones R (1998) Characterization of a strain of infectious hepatitis $\mathrm{E}$ virus isolated from sewage in an area where hepatitis $\mathrm{E}$ is not endemic. Appl Environ Microbiol 64:4485-4488.

Prado T, Silva DM, Guilayn WC, Rose TL, Gaspar AMC, Miagostovich MP (2011) Quantification and molecular characterization of enteric viruses detected in effluents from two hospital wastewater treatment plants. Water Res 45:1287-1297.

Prado T, Fumian TM, Miagostovich MP, Gaspar AMC (2012) Monitoring the hepatitis A virus in urban wastewater from Rio de Janeiro, Brazil. Trans R Soc Trop Med Hyg 106:104-109.

Rock C, Alum A, Abbaszadegan M (2010) PCR inhibitor levels in concentrates of biosolid samples predicted by a new method based on excitation-emission matrix spectroscopy. Appl Environ Microbiol 76:8102-8109.

Sano D, Fukushi K, Yoshida Y, Omura T (2003) Detection of enteric viruses in municipal sewage sludge by a combination of the enzymatic virus elution method and RT-PCR. Water Res 37:3490-3498.

Schlindwein AD, Rigotto C, Simões MO, Barardi CRM (2010) Detection of enteric viruses in sewage sludge and treated wastewater effluent. Water Sci Technol 61:537-544.

Sidhu JPS, Toze SG (2009) Human pathogens and their indicators in biosolids: A literature review. Environ International 35:187-201.

Silva AK, Le Saux JC, Parnaudeau S, Pommepuy M, Elimelech M, Le Guyader FS (2007) Evaluation of removal of 
noroviruses during wastewater treatment, using real-time reverse transcription-PCR: different behaviors of genogroups I and II. Appl Environ Microbiol 73:7891-7897.

Simmons FJ, Xagoraraki I (2011) Release of infectious human enteric viruses by full-scale wastewater utilities. Water Res 45:3590-3598.

Victoria M, Guimarães FR, Fumian TM, Ferreira FFM, Vieira CB, Shubo T, Leite JPG, Miagostovich MP (2010) One year monitoring of norovirus in a sewage treatment plant in Rio de Janeiro, Brazil. J Water Health 8:158-165.

Villar LM, de Paula VS, Diniz-Mendes L, Lampe E, Gaspar AMC (2006) Evaluation of methods used to concentrate and detect hepatitis A virus in water samples. J Virol Methods 137:169-176.

Wen Q, Tutuka C, Keegan A, Jin B (2009) Fate of pathogenic microorganisms and indicators in secondary activated sludge wastewater treatment plants. $\mathrm{J}$ Environ Management 90:1442-1447.

Zeng SQ, Halkosalo A, Salminen M, Szakal ED, Puustinen L, Vesikari T (2008) One-step quantitative RT-PCR for the detection of rotavirus in acute gastroenteritis. J Virol Methods $153: 238-240$.

All the content of the journal, except where otherwise noted, is licensed under a Creative Commons License CC BY-NC. 